Vol. 11 (2): 293-298 (2021)

\title{
SPECIES COMPOSITION OF PLANTS AS A PROXY AND A BASE FOR THE FORECAST OF FORMATION OF VEGETATION AT LONG-TERM EXPLOITATION OF OIL AND GAS CONDENSATE DEPOSIT (illustrated by the Upper Chona deposit, Irkutsk Region)
}

\author{
Alexander Sizykh ${ }^{1^{*}}$

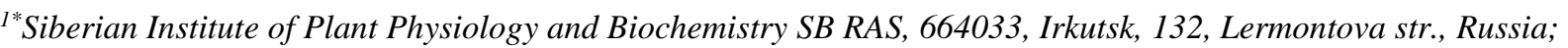 \\ *Corresponding Author Alexander Sizykh, e-mail: alexander.sizykh@gmail.com;
}

Received January 2021; Accepted February 2021; Published March 2021;

DOI: $\underline{\text { https://doi.org/10.31407/ijees11.213 }}$

\begin{abstract}
The studies of species composition of the phytocoenoses at one of oil and gas condensate deposits of the Irkutsk Region (the Upper Chona one) resulted in obtaining of basic material for indicatin of actual state and for assessment of probable changes of vegetation spatial-dynamic organization at long-term exploitation of the deposit.
\end{abstract}

Key words: plant species, proxy, forecast, oil-gas condensate deposit, Irkutsk region, Western Siberia 